\title{
Relationship between Lung Functions and Extent of Emphysema in Patients with Chronic Obstructive Pulmonary Disease
}

\author{
Muzaffer Sarıaydın ${ }^{1}$, Nejat Altıntaş², Özgür İnce ${ }^{1}$ \\ ${ }^{1}$ Department of Pulmonary Medicine, On Dokuz Mayis University Faculty of Medicine, Samsun \\ ${ }^{2}$ Department of Pulmonary and Sleep Medicine, Namik Kemal University Faculty of Medicine, Tekirdağ
}

\begin{abstract}
Objective: A study was undertaken to investigate whether the extent of emphysema, visually confirmed by high-resolution computed tomography (HRCT), in patients with COPD was associated with different indices of lung function and health-related life quality of patients with COPD.

Methods: Eighty-two patients with COPD underwent HRCT scanning; visual assessment of HRCT scan was used in the calculation of the assessment of the severity and extent of emphysematous destruction. The patients were clinically stable at the time of the evaluation. For all subjects, a detailed interview of disease history and symptoms, health-related quality of life (HRQL) measurement, and pulmonary function tests were performed.
\end{abstract}

Results: The mean visual emphysema score in all patients was $2.10 \pm 1.26$. While the mean emphysema score in patients with COPD GOLD (Global Initiative for Chronic Obstructive Lung Disease) stage 3 was $2.88 \pm 1.01$, it was $1.54 \pm 1.13$ in patients with COPD GOLD stage $2(p<0.001)$. There was a significant correlation between the percentage of pulmonary emphysema and the numbers of pack-years smoked $(r=0.58, p<0.001)$. The visual emphysema score was inversely correlated with FEVl $(r=-0.56, p<0.0001)$, FVC $(r=-0.38, p<0.001)$, FEVl/FVC $(r=-0.43, p<0.001), \operatorname{PEF}(r=-0.44, p<0,001)$ and with carbon monoxide diffusion capacity (DLCO) $(r=-0.50, p<0.001)$. There was no correlation between emphysema score and SGRQ.

Conclusion: These data suggest that HRCT visual scores correlate with functional indices of airflow obstruction and impaired lung diffusing capacity in patients with stable chronic obstructive pulmonary disease of varying severity, and the presence of pulmonary emphysema is best represented by FEVI and DLCO.

Keywords: Chronic obstructive, computed tomography, emphysema, pulmonary disease

\section{Özet}

Amaç: Bu çalş̧mada kronik obstrüktif akciğer hastalarında (KOAH), görsel amfizem skoru ile değerlendirilen amfizemin yaygınlığı ile akciğer fonksiyonlarının değişik indeksleri ve hastaların hayat kaliteleri arasındaki ilişki araştırıldı.

Yöntemler: Seksen-iki KOAH hastasına yüksek rezolusyonlu bilgisayarlı tomografi (YRBT) çekildi, amfizemin ciddiyeti ve yaygınlığının hesaplanmasında görsel amfizem skoru kullanıldı. Tüm hastalar değerlendirme esnasında stabildi. Tüm hastaların ayrıntılı hikayeleri ve semptomları kaydedildi, sağlık ilişkili hayat kaliteleri ve solunum fonksiyon testleri ölçüldü.

Bulgular: Tüm hastaların görsel amfizem skoru ortalaması $2.10 \pm 1.26$ idi. GOLD (Global Initiative for Chronic Obstructive Lung Disease) evre 3 olan hastalarda ortalama amfizem skoru $2.88 \pm 1.01$ iken GOLD evre 2 hastalarında $1.54 \pm 1.13$ idi $(\mathrm{p}<0.001)$. Pulmoner amfizem skoru ile sigara paket-yll arasinda anlamlı bir korelasyon vardl $(\mathrm{r}=0.58, \mathrm{p}<0.001)$. Görsel amfizem skorunun, FEVl $(\mathrm{r}=-0.56$, $p<0.0001), F V C(r=-0.38, p=0.001), F E V l / F V C(r=-0.43, p<0.001)$, PEF $(r=-0.44, p<0,001)$ ve karbon monoksit difüzyon kapasitesi (DLCO) $(\mathrm{r}=-0.50, \mathrm{p}<0.001)$ ile ters yönde korelasyonu vardı. Amfizem skoru ile SGRQ arasında bir korelasyon saptanmadı.

Sonuç: Bu veriler değişik şiddetdeki stabil KOAH hastalarında, YRBT görsel amfizem skorunun hava yolu obstrüksiyonunun fonksiyonel indeksleri ve azalmış akciğer difüzyon kapasitesi ile arasında bir korelasyon olduğunu ve pulmoner amfizem varlığının en iyi $\mathrm{FEV}_{1}$ and DLCO ile gösterildiğini ileri sürmektedir

Anahtar Kelimeler: Amfizem, bilgisayarli tomografi, kronik obtrüktif, pulmoner hastalik

\author{
It was presented to 2013 Turkish Thorasic Society \\ Congress as a poster presentation. \\ Received Date / Alındığı Tarih: 28.04.2014 \\ Accepted Date / Kabul Tarihi: 02.08.2014 \\ Available Online Date / \\ Çevrimiçi Yayın Tarihi: 25.11.2014 \\ Address for correspondence / Yazışma Adresi \\ Nejat Altıntaş, Namik Kemal Universitesi Tip \\ Fakültesi, Gögüs Hastalıkları Anabilim Dalı, \\ Tekirdağ \\ E-mail / E-posta: nejataltintas@gmail.com \\ (C) Copyright 2014 Turkish Respiratory Society (TRS) \\ Eurasian J Pulmonol 2014 \\ DOI: $10.5152 /$ ejp.2014.98608 \\ -Available online at www.eurasianjpulmonol.com
}

\section{INTRODUCTION}

Chronic obstructive pulmonary disease (COPD) is a major cause of morbidity and mortality worldwide and is projected to rank fifth in 2020 in burden of disease worldwide, according to a study published by the World Bank/World Health Organization (1). GOLD (Global Initiative for Chronic Obstructive Lung Disease) defines COPD as a disease state characterized by the presence of airway obstruction that is not fully reversible (1). In these patients, airflow obstruction is caused by the destruction of lung parenchyma (emphysema), airway narrowing, or both (2).

Pulmonary function testing offers a convenient tool for screening the disease earlier and assessing the progression of lung disease (3); however, the heterogeneity of disease can not be defined by FEV1 alone. The recently published guidelines of GOLD consider COPD patients as a homogeneous population, at least with regard to pharmacologic treatment (1). Accordingly, only simple spirometry is recommended to evaluate the presence and severity of airway obstruction. It is reasonable that a bet- 
ter understanding of the underlying disease may help to reduce the variability of response to therapeutic interventions in COPD patients.

High-resolution computed tomography (HRCT) scanning is considered to be a sensitive technique for detecting and quantifying pulmonary emphysema in vivo, but it may not be easy to obtain in many centers and is not suitable for follow-up (4). Studies attempting to relate pulmonary function measurements to HRCT scan yielded conflicting results, which makes it difficult to select the best functional indices that may indicate the degree of pulmonary emphysema, as evaluated by HRCT scan, the method of choice (5-7).

The aim of the present study was to examine how emphysema severity and extent affect a set of noninvasive pulmonary measures so that the extent of emphysema can be assessed by lung function tests and to determine which measurements are useful in achieving agreement with HRCT scan data in well-selected stable COPD patients with a wide range of bronchial obstructions.

\section{METHODS}

\section{Subjects}

This cross-sectional observational study recruited 82 patients (aged $63 \pm 7$ years); body mass index (BMI): $26.9 \pm 5.4 \mathrm{~kg} / \mathrm{m}^{2}$ diagnosed with COPD consecutively from September 2008 to May 2011 in the pulmonary clinic at a university hospital. All patients had complete demographic data recorded, including age, duration of symptoms, and full smoking and medical history (Table 1).

A diagnosis of COPD was made according to the criteria of GOLD, as follows: $\mathrm{COPD}=$ presence of a post-bronchodilator $\mathrm{FEV}_{1} / \mathrm{FVC}$ ratio $<70 \%$ (1). The patients were clinically stable (no exacerbation for at least 2 months) at the time of the evaluation. All subjects were smokers or past smokers who had smoked $\geq 10$ pack-years. Patients with a diagnosis of asthma, current active pulmonary tuberculosis, or any other clinically relevant lung disease (bronchiectasis, pleural effusion, any history of lung cancer, lung resection, cystic fibrosis, allergic alveolitis, or pulmonary fibrosis) and patients with bronchodilator reversibility were excluded. All patients provided written informed consent and approved by the ethical committee at the Ondokuz Mayıs University Hospital (ethical committee number=2010-144).

\section{Pulmonary Function Tests}

Pulmonary function tests (PFTs) were performed with a ZAN system (ZAN ${ }^{100}$; ZAN Gerätetechnik GmbH, Oberthulba, Germany). Forced vital capacity (FVC), forced expiratory volume in 1 second (FEV1), peak expiratory flow rate (PEFR), and reversibility testing with $400 \mu \mathrm{g}$ inhaled salmeterol were performed according to the American Thoracic Society/European Respiratory Society consensus guidelines (8). Carbon monoxide diffusing capacity $\left(\mathrm{DL}_{\mathrm{CO}}\right)$ was performed with an EasyOne Pro (EasyOne Pro; Andover, Massachusetts, USA). DL $\mathrm{C}_{\mathrm{co}}$ using the single-breath method was measured as described by Huang and Macintyre (9). FVC, FEV ${ }_{1}$ PEFR, and $\mathrm{DL}_{\mathrm{CO}}$ were expressed as percentage of predicted values (8).

\section{CT Scans and Reading of Images}

Low-attenuation areas (LAAs) were quantified by HRCT scan. CT scans were performed in a supine position using spiral CT scanners (Discovery CT750HD; GE Healthcare, Milwaukee, WI, USA or Somatom; Siemens Healthcare, Erlangen, Germany). No contrast media was used. CT scans were obtained after deep inspiration. This minimized the influence of variable hyperinflation, allowed us to compare the results under the same conditions, and optimized breath-holding time. An experienced chest radiologist made the interpretation, unaware of the clinical and lung function data. The reader viewed the images on a high-resolution monitor in its typical window and level settings with maximum magnification while scrolling through the images one by one. Interpretations were performed using standard lung settings (collimation, $1.5 \mathrm{~mm}$; width, 1500 Hounsfield units; level, -650 Hounsfield units).

\section{Visual Emphysema Score}

Emphysema was identified as areas of hypovascular low attenuation. On three HRCT slices (at the level of the carina and $5 \mathrm{~cm}$ above and 5 $\mathrm{cm}$ below the carina), the lung parenchyma was assessed for extent of emphysema. The three levels were graded and scored separately for the left and right lung, giving a total of six lung fields. Emphysema distribution was graded with a 5-point scale based on the percentage of lung involved: 0 , no emphysema; 1 , up to $25 \%$ of lung parenchyma involved; 2 , between $26 \%$ and $50 \%$ of lung parenchyma involved; 3 , between $51 \%$ and $75 \%$ of lung parenchyma involved; and 4 , between $76 \%$ and $100 \%$ of lung parenchyma involved.

\section{St George's Respiratory Questionnaire}

The St George's Respiratory Questionnaire (SGRQ) was used to assess health-related quality of life. This is a supervised self-administered measure, designed specifically for use in respiratory disease, and contains three domains: symptoms (relating to cough, sputum, wheeze, and shortness of breath); activity (relating to physical activity limited by breathlessness); and impact (relating to control, panic, medication, and expectations) (10). A total score was calculated from all three domains.

\section{Statistical Analysis}

The normality of the data distribution was assessed by the Shapiro-Wilks test. Pearson's correlation coefficient was used to determine relationships between normally distributed or log-transformed variables; otherwise, Spearman's rank test was used. Independent-sample t-tests were utilized in comparing means between groups with dichotomous data. Two-sided $p$ values $<0.05$ were considered statistically significant. Data were analyzed using SPSS statistical software (Mac version 21.00, serial number; 10229569, SPSS Inc, Chicago, IL, USA).

\section{RESULTS}

A total of 167 patients with COPD from a university hospital were recruited. We were able to perform clinical and radiological evaluations for 128 patients. Of these, 46 were not included in the study, because they had clinically relevant pulmonary problems. Thus, the final population had 82 male patients, whose clinical and demographic data are shown in Table 1. The flow chart for the selection of the participating patients is shown at Figure 1.

Of these 82 patients, 48 patients had moderate obstruction (GOLD stage 2), and 34 patients had severe obstruction (GOLD stage 3). Table 1 shows the patients' pulmonary function characteristics.

The mean visual emphysema score in all patients was $2.10 \pm 1.26$. The mean visual emphysema score was higher in patients with COPD GOLD stage 3 than in patients with GOLD stage 2: $2.88 \pm 1.01$ vs. 


\section{COPD patients}
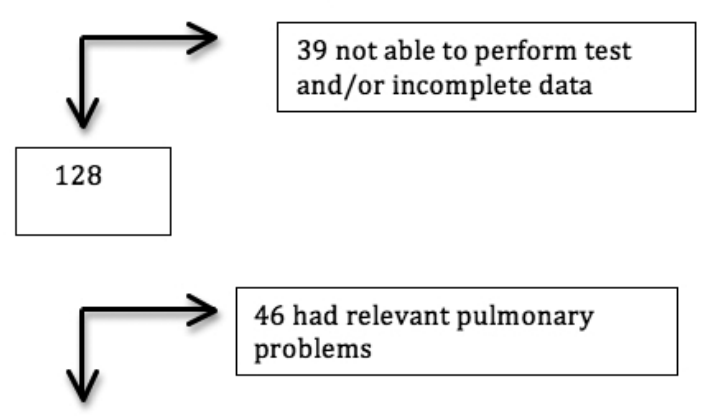

82

Figure 1. Flow chart for the selection of the participating patients

$1.54 \pm 1.13$, respectively $(p<0.001)$. The majority of stage 3 patients had visual emphysema score 3 , whereas stage 2 patients had visual emphysema score 1 . The percentage of patients according to visual emphysema score is shown in Figure 2.

The BMI was lower in patients with GOLD stage 3 than GOLD stage 2: $28.7 \pm 5.3 \mathrm{~kg} / \mathrm{m}^{2}$ versus $24.4 \pm 4.5 \mathrm{~kg} / \mathrm{m}^{2}$, respectively $(\mathrm{P}<0.0001)$ (Table 2 ).

There was a significant correlation between the percentage of pulmonary emphysema and the numbers of pack-years smoked $(r=0.58$, $p<0.001)$. The visual emphysema score was inversely correlated with FEV $_{1}(r=-0.56, p<0.0001)$, FVC $(r=-0.38, p=0.001), F_{1} / F V C(r=-0.43$, $\mathrm{p}<0.001), \operatorname{PEF}(\mathrm{r}=-0.44, \mathrm{p}<0.001)$, and $\mathrm{DL}_{\mathrm{CO}}(\mathrm{r}=-0.50, \mathrm{p}<0.001)$ (Table 3$)$.

No correlation was found between the emphysema score and FEV1\% change and SGRQ. The relationships of emphysema score with lung function parameters and arterial blood gases are reported in Table 3.

\section{DISCUSSION}

The main finding of the present study is that an increase in visual emphysema score, evaluated by thorax HRCT, results in decreased lung functions, airflow obstruction, and decreased carbon monoxide diffusion test, and of these parameters, presence and severity of emphysema correlate best with FEV1 and impaired gas exchange capability in patients with different severities of COPD, based on GOLD criteria.

Chronic obstructive pulmonary disease is a very inhomogeneous condition, and a better characterization of the phenotype of the disease may help to reduce the variability of response to therapeutic interventions in COPD patients (11). Spirometry is widely used to evaluate the presence and severity of airway obstruction, while the assessment of emphysema by HCRT scan is restricted to those patients who are possible candidates for surgery (12). In the last few years, great attention has been paid to drugs that specifically address either airflow obstruction (e.g., phosphodiesterase inhibitors) or parenchymal damage (e.g., $a_{1}$-antitrypsin augmentation therapy). From this perspective, the variability of response to treatments could be reduced by assessing patients for the presence and extent of emphysema (12).

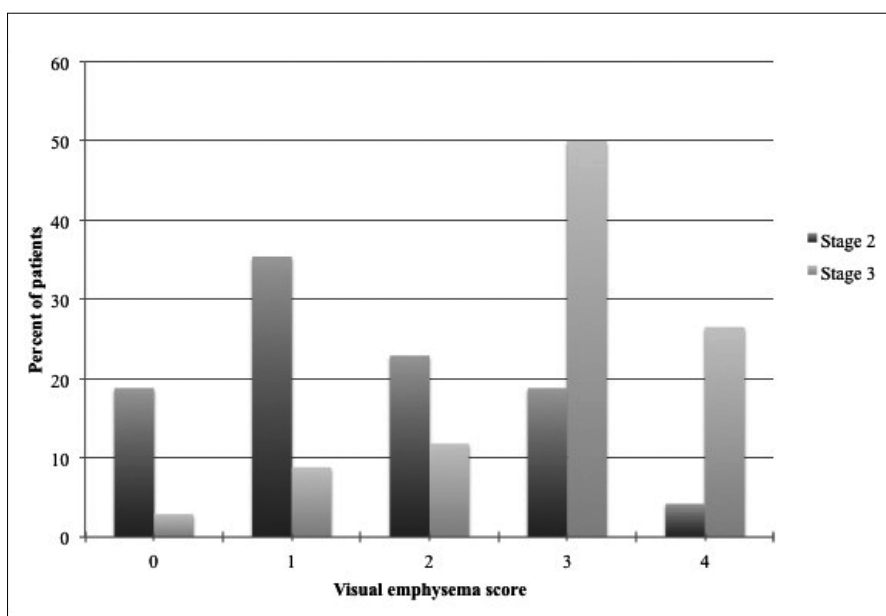

Figure 2. Percentage of patients according to visual emphysema score

Table 1. Demographic, clinical, and physiologic characteristics of the patients

\begin{tabular}{|c|c|}
\hline Characteristics & Mean \pm SD \\
\hline Age, year & $63 \pm 7$ \\
\hline Body mass index, $\mathrm{kg} / \mathrm{m}^{2}$ & $26.9 \pm 5.4$ \\
\hline COPD duration, year & $5.6 \pm 2.7$ \\
\hline Smoking, pack-years & $55.0 \pm 8.3$ \\
\hline${ }^{*} \mathrm{FEV}_{1}$ change, $\%$ predicted & $2.4 \pm 1.9$ \\
\hline $\mathrm{FEV}_{1}, \%$ predicted & $53.1 \pm 12.0$ \\
\hline FVC, \% predicted & $70.6 \pm 13.1$ \\
\hline FEV1/FVC (\%) & $55.0 \pm 9.2$ \\
\hline PEF \% & $51.6 \pm 16.1$ \\
\hline FEF $25-75 \%$ & $23.1 \pm 7.9$ \\
\hline $\mathrm{DL}_{\mathrm{CO}^{\prime}} \%$ predicted & $56.3 \pm 17.1$ \\
\hline Total SGRQ & $54.4 \pm 12.9$ \\
\hline \multicolumn{2}{|c|}{ *Reversibility testing with $400 \mu \mathrm{g}$ inhaled salmeterol. } \\
\hline \multicolumn{2}{|c|}{ 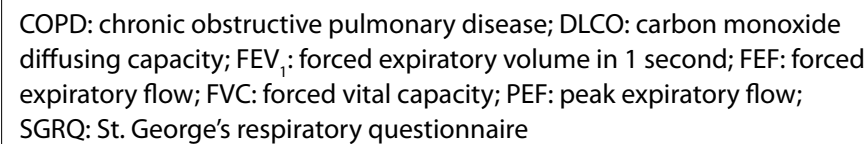 } \\
\hline
\end{tabular}

Table 2. GOLD stages of COPD and visual emphysema score

\begin{tabular}{|l|c|c|c|}
\hline $\begin{array}{l}\text { COPD GOLD Stage } \\
\text { (Number of patients) }\end{array}$ & $\begin{array}{c}\text { Stage 2 } \\
(\mathrm{n}: 48)\end{array}$ & $\begin{array}{c}\text { Stage 3 } \\
(\mathrm{n}: 34)\end{array}$ & p value \\
\hline Body mass index, $\pm \mathrm{SD},\left(\mathrm{kg} / \mathrm{m}^{2}\right)$ & $28.7 \pm 5.3$ & $24.4 \pm 4.5$ & $<0.0001$ \\
\hline Mean visual emphysema score $\pm S D$ & $1.54 \pm 1.13$ & $2.88 \pm 1.01$ & $<0.0001$ \\
\hline
\end{tabular}

Evaluation of emphysema by HRCT is a noninvasive method that best assesses the severity, extent, and progression of emphysema in clinical practice; however, the use of HRCT scanning for the assessment of emphysema has some limitations. First, it may not be easy to obtain in a number of centers. Second, it exposes the patient to radiation. Third, it can not be taken as an indisputable "gold standard" for the 
quantification of emphysema, as it provides correlation coefficients, with lung pathology ranging from 0.7 to 0.9 (13). However, lung function tests are easy to obtain in most centers, but the relationships between single parameters and the extent of emphysema, determined either by pathology or HRCT scan, are rather weak. The present study gives an answer to the two following practical questions: first, how the severity and extent of emphysema affect a set of noninvasive pulmonary measures, and secondly, whether the extent of emphysema can be assessed by lung function tests and which measurements are useful in achieving agreement with HRCT scan data.

We used a subjective method for the estimation of emphysema-i.e., visual score (14). It has been reported that the analysis of visual scoring may lead to a systematic overestimation of emphysema (15). However, the majority of studies has shown reasonably good correlations between CT emphysema scores and the pathological specimen, a good agreement between expert readers for the assessment of the presence and extent of emphysema, and good correlations between subjective and objective assessments of emphysema (7). Our finding is in agreement with previous studies in which the visual emphysema score is inversely correlated with FEV1, FVC, FEV1/FVC, PEF, and DL $(7,12)$. Visual emphysema score correlated inversely best with FEV1 and $\mathrm{DL}_{\mathrm{CO}}$ in our study; however, it correlated inversely best with $\mathrm{FEV}_{1}$ / FVC and $\mathrm{DL}_{\text {CO }}$ in a previous study (7).

In our study, there was also an inverse relationship between visual emphysema score and $\mathrm{DL}_{\mathrm{co}}$. Diffusion capacity is reduced in emphysema patients because of the loss of alveolar-to-capillary surface, but it also may be decreased due to very severe airway obstruction.

Our data suggest that the presence of pulmonary emphysema is best represented by $\mathrm{FEV}_{1}$ and the impaired gas exchange capability of the respiratory system in patients with stable chronic obstructive pulmonary disease of varying severity.

We observed a statistically significant correlation between HRCTscored emphysema and number of pack-years smoked. These findings are in agreement with a study by Patel and colleagues (16), who found a significant relationship between pack-years smoked and emphysema in a large group of COPD patients.

In our study, there was no correlation between emphysema score and quality of life measured by the SGRQ, because the presence of emphysema had less impact on the clinical presentation of patients in our group. This is an important finding, which is in accordance with previous reports (17). It has been estimated that $30 \%$ of the lung must be destroyed by emphysema before symptoms become evident (18). It is possible that with such small degrees of emphysema, mechanisms other than changes in elastic recoil may be responsible for the physiologic impairment.

Mair et al. (19) analyzed variables that might predict the severity of emphysema and found that BMI was the best predictor. In our study group, we found a strong inverse correlation between BMI and the extent of emphysema, which correlates with the knowledge that BMI is tightly associated with emphysema, at least in patients with normal BMI and diffuse emphysema.

As a result, it may be argued that the knowledge of the presence of emphysema is not important. One could postulate that knowing whether emphysema exists in patients with moderate or severe
COPD adds little to the clinical management. However, FEV 1 correlates weakly with clinical outcomes and health status in patients with COPD (20). Moreover, because FEV $\mathrm{F}_{1}$ is a global measurement of lung function, it can not capture the heterogeneity of COPD or its many different clinical phenotypes. The advent of novel pulmonary imaging methods that can be rapidly and safely deployed has enabled COPD research to move beyond $\mathrm{FEV}_{1}$ by facilitating and amplifying clinical phenotyping measurements, providing quantitative information, and detecting significant responses to therapy, even in the absence of significant FEV improvements. For example, until recently, it was unclear why patients with COPD using inhaled bronchodilators experienced significant symptomatic improvements despite very modest improvements in FEV . Now, the picture is clearer, because pulmonary imaging techniques provide a way to visualize and quantify regional improvements in ventilation over time and in response to bronchodilator therapy, even in the absence of clinically relevant changes in $\mathrm{FEV}_{1}$ (21). Furthermore, the presence of emphysema significantly increases the risk of lung cancer in these patients (22). For this reason alone, we believe that identifying emphysema in patients with COPD is important for their long-term care.

\section{Study Limitations}

The small sample size is a limitation of this study. The lack of women is also important, as it is now well known that there are important sex differences in the severity and distribution of emphysema. Women have less severe emphysema than men, and it is generally centrally distributed, with smaller areas of low attenuation (18). This limitation precludes an assessment of the role that the presence, severity, and distribution of emphysema might have on the clinical presentation of the disease in women. Knowing that there are consistent sex differences in the clinical presentation of the disease, we believe it is important to further investigate this issue with an appropriate cohort. Finally, because our study population was limited to patients with moderate to severe COPD, these findings can not be extrapolated to patients with preserved lung function and emphysema.

\section{CONCLUSION}

In conclusion, in this group of patients with moderate to severe COPD, the presence of emphysema, regardless of its distribution, has an impact on physiologic parameters but not on the clinical presentation of the disease. As documented in the present study, lung function tests have some limitations as regards the measurements of airway obstruction and lung dysfunction, particularly in patients with predominant pulmonary emphysema; however, the use of well-selected and appropriate lung function measurements may be helpful in giving an estimate of the extent of emphysema in the follow-up monitoring of patients with COPD. Further studies should confirm the importance of our findings.

Ethics Committee Approval: Ethics committee approval was received for this study from the ethics committee of 19 Mayis University.

Informed Consent: Written informed consent was obtained from patient who participated in this study.

Peer-review: Externally peer-reviewed.

Author contributions: Concept - M.S., N.A., O.I.; Design - M.S., N.A. ; Supervision M.S., N.A., O.I.; Resource - M.S., N.A., O.I.; Materials - M.S., N.A., O.I.; Data Collection\&/or Processing - M.S.; Analysis\&/or Interpretation -N.A.; Literature Search - N.A.; Writing - N.A.; Critical Reviews - M.S., N.A., O.I.

Conflict of Interest: No conflict of interest was declared by the authors. 
Financial Disclosure: The authors declared that this study has received no financial support.

\section{REFERENCES}

1. Rabe KF, Hurd S, Anzueto A, Barnes PJ, Buist SA, Calverley P, et al. Global strategy for the diagnosis, management, and prevention of chronic obstructive pulmonary disease: GOLD executive summary. Am J Respir Cri Care Med 2007; 176: 532-55. [CrossRef]

2. Celli BR, MacNee W, ATS/ERS Task Force. Standards for the diagnosis and treatment of patients with COPD: a summary of the ATS/ERS position paper. Eur Respir J 2004; 23: 932-46. [CrossRef]

3. Eisner MD, Iribarren C, Yelin EH, Sidney S, Katz PP, Ackerson L, et al. Pulmonary function and the risk of functional limitation in chronic obstructive pulmonary disease. Am J Epidemiol 2008; 167: 1090-101. [CrossRef]

4. Bankier AA, Madani A, Gevenois PA. CT quantification of pulmonary emphysema: assessment of lung structure and function. Crit Rev Comput Tomogr 2002; 43: 399-417. [CrossRef]

5. Madani A, Keyzer C, Gevenois PA. Quantitative computed tomography assessment of lung structure and function in pulmonary emphysema. Eur Respir J 2001; 18: 720-30. [CrossRef]

6. Makita H, Nasuhara Y, Nagai K, Ito Y, Hasegawa M, Betsuyaku T, et al. Characterisation of phenotypes based on severity of emphysema in chronic obstructive pulmonary disease. Thorax 2007; 62: 932-7. [CrossRef]

7. Park KJ, Bergin CJ, Clausen JL. Quantitation of emphysema with three-dimensional CT densitometry: comparison with two-dimensional analysis, visual emphysema scores, and pulmonary function test results. Radiology 1999; 211: 541-7. [CrossRef]

8. Miller MR, Crapo R, Hankinson J, Brusasco V, Burgos F, Casaburi R, et al. General considerations for lung function testing. Eur Respir J 2005; 26: 153-61. [CrossRef]

9. Huang YC, Macintyre NR. Real-time gas analysis improves the measurement of single-breath diffusing capacity. Am Rev Respir Dis 1992; 146: 946-50. [CrossRef]

10. Jones PW, Quirk FH, Baveystock CM, Littlejohns P. A self-complete measure of health status for chronic airflow limitation. The St. George's Respiratory Questionnaire. Am Rev Respir Dis 1992; 145: 1321-7. [CrossRef]

11. Marsh SE, Travers J, Weatherall M, Williams MV, Aldington S, Shirtcliffe PM, et al. Proportional classifications of COPD phenotypes. Thorax 2008; 63: 761-7. [CrossRef]
12. Cerveri I. Assessment of Emphysema in COPD*A Functional and Radiologic Study. Chest 2004; 125: 1714-8. [CrossRef]

13. Coxson HO. Quantitative computed tomography assessment of airway wall dimensions: current status and potential applications for phenotyping chronic obstructive pulmonary disease. Proc Am Thorac Soc 2008; 5: 940-5. [CrossRef]

14. Gurney JW, Jones KK, Robbins RA, Gossman GL, Nelson KJ, Daughton D, et al. Regional distribution of emphysema: correlation of high-resolution CT with pulmonary function tests in unselected smokers. Radiology 1992; 183: 457-63. [CrossRef]

15. Litmanovich D, Boiselle PM, Bankier AA. CT of pulmonary emphysema--current status, challenges, and future directions. Eur Radiol 2009; 19: 537-51. [CrossRef]

16. Patel BD, Coxson HO, Pillai SG, Agustí AGN, Calverley PMA, Donner CF, et al. Airway wall thickening and emphysema show independent familial aggregation in chronic obstructive pulmonary disease. Am J Respir Cri Care Med 2008; 178: 500-5. [CrossRef]

17. Boschetto P, Quintavalle S, Zeni E, Leprotti S, Potena A, Ballerin L, et al. Association between markers of emphysema and more severe chronic obstructive pulmonary disease. Thorax 2006; 61: 1037-42. [CrossRef]

18. de Torres JP, Bastarrika G, Zagaceta J, Sáiz-Mendiguren R, Alcaide AB, Seijo LM, et al. Emphysema presence, severity, and distribution has little impact on the clinical presentation of a cohort of patients with mild to moderate COPD. Chest 2011; 139: 36-42. [CrossRef]

19. Mair G, Miller JJ, McAllister D, Maclay J, Connell M, Murchison JT, et al. Computed tomographic emphysema distribution: relationship to clinical features in a cohort of smokers. Eur Respir J 2009; 33: 536-42. [CrossRef]

20. Jones PW. Health status and the spiral of decline. COPD 2009; 6: 59-63. [CrossRef]

21. Coxson HO, Leipsic J, Parraga G, Sin DD. Using Pulmonary Imaging to Move Chronic Obstructive Pulmonary Disease beyond FEV1. Am J Respir Cri Care Med 2014; 190: 135-44. [CrossRef]

22. Zulueta JJ, Wisnivesky JP, Henschke Cl, Yip R, Farooqi AO, McCauley DI, et al. Emphysema scores predict death from COPD and lung cancer. Chest 2012; 141: 1216-23. [CrossRef] 